\title{
Organization of the U.S.D.A. Library as Indicated by Its Organization Charts
}

Mr. Shaw, librarian, U.S. Department of Agriculture, read this paper at the Agricultural Libraries Section of A.C.R.L., June 22, 1942.

$A^{N}$ ORganization CHART represents 1 the family skeleton of an institution. Like statistics it can be presented in many forms and is subject to widely varying interpretation. It is the reductio $a d a b$ surdum of a great mass of strictly human interrelationships (and, therefore, must show hierarchy); it is the blueprint for a quasi-engineering job of production in the field of public administration (and, therefore, must show flow of work); it is a graphic form for presenting the relative weight or importance of segments of the institution's fields of work (and, therefore, must show types of responsibility as distinguished from hierarchy or levels of responsibility); it must show where each type of work is actually performed and levels of administrative and functional responsibility; it should mirror the government of the institution, as well as its administration, its objectives, the nature or at least the composition of its clientele, and its relationship to other institutions, among other things.

Still further, it reflects the philosophy of administration under which the institution labors at the moment (i.e., line or military organization vs. functional organization or some combination of the two).

All this is true, of course, only so long as the organization chart truly reflects the organization under which the institution is operating-which, I fear, is not always the case.

Furthermore, since it is usually the latest edition of the family skeleton and is exposed to the general view in one dimension only, there is a tendency (again as in the case of statistics) to exhibit the most favorable view of the skeleton and to polish the bones where exposed. Like the preface of a book, the organization chart should tell us what the author is trying to do, how, to whom, why, and so on.

As indicated by the McDiarmids' "An Approach to the Problems of Library Organization" 1 and by Howard, "The Functions of Library Management,", we librarians generally know so little about either organization or management that our organization charts are probably really good charts of confused organizational and managerial pictures (which point is probably well illustrated by our own chart).

A true organization chart of an institution at any moment offers a key to goals

1 Library Quarterly 9:133-44, April 1939.

2 Library Quarterly Io:3 1 3-49, July 1940. 
to which it aspires, the methods of operation, the personalities which enter into the formulation of its policies and methods, the present functions and those envisioned, the staff and line relationships; in fact, if properly made and properly interpreted, the organization chart should expose the stuff and dreams of which the institution is composed; its people and its things and its doings; its past, present, and its immediate future.

Thus, it is with considerable diffidence that I lay before you the organization of the Department of Agriculture Library, as exposed in its current organization chart.

\section{"From Plural to Singular"}

The most fundamental organizational change which has taken place in the department library system during the last year may be summarized in four words, "from plural to singular." A year ago it was "Department of Agriculture libraries" in the full sense of that term. Of course, we had coordination through the department librarian to a certain extent, and the books were all the property of the department library (meaning, at that time, the main library but not the bureau libraries). Essentially we had more or less a system of libraries consisting of the main library and a number of bureau libraries, variously calculated, including a large number of more or less autonomous field branches, which were more or less under the bureau libraries.

By vast oversimplification of a complex and nonuniform relationship under our organizational pattern of several years ago, we might say that the main library was the builder of potential for service and the bureau libraries were the internal service agencies, while the main library was the primary service agency to all outside the department. However, the complexity of the pattern of relationships and gaps in relationship, together with their frequent and basic changes, defied compilation into a single graphic presentation, and generalizations about that structure would be quite unsound. The department library served when called upon, loaned books, did much of the cataloging, bought some of the books, did a little of the basic bibliographical work, and offered reference services. The bureaus did their own book selection and purchasing in those cases in which bureau funds were available for the purchase of books, did their own cataloging, all did their own periodical routing, most compiled some bibliographical tools, and all assumed varying degrees of responsibility for extension of service to the field. They all operated primarily on bureau lines rather than on subject matter lines.

\section{Former Organizational Chart}

Since the functions of the department library were designed primarily for the building of potential for service, its organization chart of ten or fifteen years ago quite properly showed the following four divisions: first, an administrative office, which included the procurement of publications; second, cataloging; third, periodicals, which were all concerned with the collection and organization of material for use; and fourth, the smallest of all, the reference division.

At that stage of the library's ontogeny there was no formal organization for coordination of the library and bibliographical work of the department and no organization for general field service.

More recently, emphasis was placed on unification of all the libraries into a system. 
Under this change, while there was somewhat more tendency toward coordination, the bureau libraries were still rather more independent libraries than they were part of a system. They still operated on bureau lines rather than on subject lines, and there was still a considerable amount of duplication of collections, technical processes, and services. About a year and a half ago a definite program for coordination of bureau libraries on subject lines was agreed upon, and that was reflected in the organization chart by addition of a coordinator of bureau libraries.

Still, such service as was rendered to the very large portion of the department staff which was not in Washington was limited to occasional loans from Washington and, to a limited extent, low-grade routine services from a number of scattered, very small bureau field libraries without professional staff except in one or two cases and with varying but very limited supervision from the bureau libraries in Washington.

A further stage in the development of field service, which was shown by the organization chart for the first time last year, was a division of field library services, which was intended to render to all the staff in the field service comparable to that provided to the staff members in Washington. Even in this picture, though, we still had the semi-independent bureau libraries and the quite independent field bureau libraries, as well as some division libraries and others that would defy classification.

\section{Consolidation}

Again conditions changed and pressing problems involved in decentralization and deconcentration of the department's work, together with the continuing difficulties caused by the transfer of two bureaus from the department to other agencies and the load of war work which tripled our reference load, resulted in consolidation of all library and bibliographical work of the department.

That again was reflected in the organization chart which now shows the office of the librarian, with its administrative unit to handle all staff services; a division of technical processes, which handles all of the acquisition, cataloging, periodical and serials work, and other technical routines; and three service divisions, viz., the division of reading and reference services, manned by personnel with considerable experience both in library work and in the subject literature in which they specialize; a division of field library services, with its system of branches that has been described by Mrs. Buhler; and a division of bibliography, which has as its task the conversion of all of the literature into a more readily useful form for specific purposes chiefly by means of: I. Liaison staff; 2 . Current literature lists, such as Agricultural Economics Literature, Entomology Current Literature, Plant Science Literature, etc.; 3. Special bibliographies prepared as exhaustive surveys of subject fields of interest to the work of the men in the department ; and 4. More limited "Library Lists" of which numbers one and two have been issued; 5. A copying section; and 6. A translation section, as well as other units for making the content of literature readily available.

It is very interesting to note that ten or fifteen years ago our work was divided one quarter into service and three quarters into technical processes, whereas under our latest organization of work this is reversed, with approximately 35 per cent of our staff time going into technical proc- 
esses and approximately 65 per cent going into the three service divisions. Likewise, where we had one service division and three technical divisions, we now have one technical and three service divisions.

\section{Changing Pattern}

Thus, the work of the department library has been reflected in a more or less regularly changing pattern on its organization chart, and its present state reflects current operations designed to meet current needs insofar as they can be determined and insofar as funds to pay for them can be secured.

It seems unquestionable that further change in this organization will be made necessary by the shifting emphasis of our work owing to the war effort. The range of the work of the department library, even now, calls for different subdivisions within these divisions than were necessary six months or a year ago. In any live organization, if the organization charts were kept up to the minute, they would probably show a cycle of change beginning in the subsections, some of which would increase in importance until they became sections and might go on growing in importance until they became major divisions of the organization, while others either just hold their own or fade off from divisions to sections, subsections, and, finally, out of the picture entirely. A number of projects within the divisions have already been displaced by the great pressure of demand of the war agencies, and more will be. Certain others are now taking their places.

As an indication of the range of reference and bibliographical work now covered by the library, it may be of interest to note the content of a single batch of mail received recently. In addition to the usual run of book business, interlibrary loan requests, and other routine matters, there was a letter which read as follows:

Dear Uncle Sam:

I am a city slicker who does not know from nothing about farming but I am willing to learn.

And then he goes on to present as neat a reader's advisory question as ever graced a reader's advisory desk in a public library, giving his background, the types of farming he was interested in, the location, etc., so a sound job could be done for him.

In the same sheaf of letters was one from the director of extension of one of our Southern states, which says:

We are very much interested in the work being done in the various states of the country in servicing rural people with library service. We are wondering if you have or can obtain for us a brief statement on the service being rendered in each state of the country.

\section{Requests from Government Agencies}

There was also one from the War Relocation Authority wanting a complete review of the literature on the Japanese in American agriculture, together with a number of other requests from the Army, Navy, O.E.M., O.P.A., and other war agencies.

Also, a request for a survey of the literature on cinchona trees in a specified area, followed by requests from department sources for material ranging from an extensive research on lousicides for camp louse control to recommendation of methods for reproducing specimens photographically, after which was a request for a survey of the literature on rationing, contrasted with a request from a high school child in Georgia who asked for a complete bibliography on wooden ships 
and a request for a packet for agricultural war boards to give them the background of the "Food for Freedom program."

Among the emerging tasks of the library appears to be the one of acting as a clearing house for bibliographical studies in our fields for the department as well as for other Federal and state agencies and, possibly, eventually for scholars in our fields in general.

There is a considerable amount of time spent in doing over again bibliographical studies that have been done before. One very good case in point is that of guayule, on which surveys of the literature were started by a number of bureaus simultaneously. When these were all merged into a single good bibliography, we found that some field agencies were also making surveys of the literature on guayule. When they were told of the existence of a comprehensive bibliography and stopped doing it over again, we found that one of the land-grant colleges had a special consultant spending a considerable amount of time on a very inadequate bibliography on guayule, chiefly because the college's potential for doing that survey was not very great. Probably others were also engaged in this unnecessary duplication of effort. A clearing house for such efforts may well develop into an important part of the library's work in normal times.

\section{Bibliographical Searching}

Another type of service that has been on the increase is provision of fundamental bibliographical searching, which requires the potential available in Washington that is not duplicated elsewhere. To this end we have attempted to develop a staff of bibliographers with some subject competence, and progress has been made in that respect.
It would seem logical also that duplication among bibliographical publications issued within the department library be eliminated and that the effort saved thereby be applied on preparing a comprehensive bibliography of the literature of agriculture. We hope very shortly to present a "Bibliography of Agriculture" in the place of the numerous bibliographical services that we are now issuing. For the time being, it will have to be limited in scope approximately to that of the bibliographical services it replaces. As duplication is eliminated, more coverage will be added, and it is hoped eventually to cover the whole literature of agriculture. If we could effect a cooperative arrangement under which each of our land-grant colleges and universities would undertake to index a certain number of periodicals, we could very quickly get coverage of the whole field of agriculture, even though we may not be able to do it by ourselves in the near future.

Against these needed services we must balance the fact that our work load has more than tripled in the last year because of the fundamental need for information that will help in fighting the war. It may very well be that for the next few years we may have to backtrack on our general services in order to provide to the military and other war agencies services that they must have in order to do their jobs.

Reduction of paper allotments has forced us to boil down all bibliographical services and will probably eliminate several of them. A gricultural Library Notes is definitely slated to go but much of its content will be covered from subject points of view in subject bibliographies. Others will probably be changed from bureau lines to subject divisions: thus, Cotton Literature, for example, will probably be 
divided among the "Agricultural Economics," "Plant Science," and "Agricultural Engineering" sections of the Bibliography of Agriculture, thus eliminating duplication and making it possible to continue coverage at least on its present level for the immediate future.

Our general services are being scrutinized thoroughly. We have simplified our cataloging and other technical processes to a considerable extent and will probably have to go even further in that respect.

\section{Reduce Interlibrary Loans?}

Another field in which the current services may possibly have to be reduced is that of interlibrary loans. Interlibrary loans have increased greatly in the last year with the increased activity in the other government agencies and the new government agencies, as well as land-grant colleges and universities and other colleges and universities. Since much of our war service is of the type in which the answer is really needed two days before the question is asked, it is possible that we may have to restrict interlibrary loans, possibly even going so far as to use the method that Columbia University and other scholarly libraries have adopted recently: saying that we will not lend anything of which a microfilm or photostatic copy can be supplied for a dollar or less. That is in the future, and I hope that we can avoid it, but it is impossible to determine at the present time just how far we shall have to go in reduction of these basic services in order to concentrate on immediate and pressing war problems.

Another field to which we have given some thought but which has not been thought all the way through yet, is the possibility that if we should succeed in developing our bibliography of agriculture to such an extent that it indexes everything received in the library and if we prepare an annual subject index to the bibliography of agriculture, with cumulative indexes every five or ten years, it might be possible to do away with the catalog entirely. If that were done, we would no longer need a catalog section as now constituted in our division of technical processes. That again is something that only the future can decide but it is an attractive thought because it would make the whole literature of agriculture, both of the type that goes into our catalog and of the type that goes into the bibliographies, available to everyone who wanted it throughout the country, and it would convert still more of our fundamental housekeeping work into a tool of value to the country as a whole.

\section{Structural Changes}

The war changes noted above have already resulted in structural changes shown in our organization chart and will probably cause still more changes. The other possibilities listed above may or may not come into the picture. If they should come to pass, they will necessitate changes in the organization, and if they do not, others should so long as our library continues to be a living force in the agricultural administration and research of our country.

We have presented the various skeletons of the library of the Department of Agriculture. There has been a constant series of changes throughout the years accelerated in recent years because of the accelerated rate of change of the department itself and the drastic changes in nature, scope, and problems of the work of the (Continued on page 59) 


\section{Katharine L. Sharp Scholarship}

$\mathrm{T}$

he Katharine L. Sharp scholar-

SHIP, which carries a stipend of three hundred dollars and exemption from tuition, will be awarded by the faculty of the University of Illinois Library School in March 1943. The award is made for the second year of study in library science. Application should be filed with the director of the school, Carl M. White, Urbana, 1ll., before March I. Application blanks may be secured upon request.

This scholarship was endowed in $\mathbf{1 9 3 3}$ by the University of Illinois Library School Association as a memorial to the founder of the library school. The present Katharine L. Sharp scholar is Agnes Reagan, who completed her first year of library school training at Emory University Library School, Emory, Ga. Since I 939 she has been on the library staff at Agnes Scott College, Decatur, Ga. Others who have held this scholarship are:
Lucy B. Foote, head cataloger, Hill Memorial Library, Louisiana State University, University.

Donald W. Kohlstedt, librarian, Public Library, Grand Rapids, Mich.

Mary E. Silverthorn, assistant professor, Library School, Ontario College of Education, University of Toronto, Toronto, Ont., Canada.

Katherine A. Brose, head, Loan Department, Mills College Library, Mills College, Calif.

Ruth M. Heiss, Technology Division, Public Library, Cleveland, Ohio.

Felix Snider, librarian, East Carolina Teachers College, Greenville, N.C.

Mr. Marion A. Milczewski, executive assistant, Books for Latin America Project, American Library Association, Washington, D.C.

Katharine Kinder, readers' adviser, Williston Memorial Library, Mount Holyoke College, South Hadley, Mass.

\section{Organization of the U.S.D.A. Library as Indicated by Its Organization Charts}

(Continued from page 34)

library. These changes are not presented as improvements; they prove nothing out of their context of the organizational and operational needs and conditions of their time and place; they indicate that through the years there has been an effort to keep our library's organization geared closely to the sum total of operating factors and that that process is still going on.
The process of growth and fission and sloughing off of dead branches is one interesting tale told by our organization charts over the years. This and much more can be found in these charts, but we must remember that the charts offer merely one-dimensional skeletons to which our staff adds life and purpose and perspective. 